\title{
Characteristics of Financial Analysis in Evaluation of Activity of The Leased Object
}

\author{
Latipova Shakhnoza Mahmudovna ${ }^{1}$, Khotamkulova Madina Sanjar kizi ${ }^{2}$ \\ ${ }^{1}$ Lecturer, ${ }^{2}$ Student \\ ${ }^{1,2}$ Samarkand Institute of Economics and Service
}

\begin{abstract}
The article pays special attention to the assessment of the lessee's performance through a multi-factorial assessment and its creditworthiness. The indicators used in the complex assessment of the financial condition of the lessee, their essence and ways to determine them are given. Foreign experience in the complex financial assessment of the activities of lessees in the leasing market was studied and scientific recommendations for its application in the national leasing market were given.
\end{abstract}

\section{Keywords}

financial analysis, profitability, liquidity, rating indicators, rating ratings, score estimates, Fishburn scheme.

\section{Introduction}

In a leasing project, the financial evaluation of the lessee is one of the key components of the leasing process. The main goal of the lessee's assessment and design phase is to minimize the risks to the lessee's activities in the implementation of the leasing relationship through the development of measures to prevent protection against economic losses.

Numerous publications and scientific views on the financial condition and analysis of business entities, in particular leasing debtors, have been published by local and foreign authors. As a result of their study, it can be concluded that the study and evaluation of the effectiveness of business entities has always been one of the important issues for the parties (managers, property owners, creditors and counterparties).

\section{Literature review}

A.U. Burkhanov, one of our national economists, has focused on the issues of financial analysis of the activities of economic entities (industrial enterprises) in his scientific works. The financial stability ratios proposed by the scientist are used to express the distribution of risk between the business entity and its creditors [1]. The issues of liquidity of business entities were widely covered by economists B.J. Khakimov and U. Kholmirzaev, who focused on the importance of money in the structure of financial assets [2].

M. Rakhimov analyzed the financial condition of economic entities and defined this concept as an economic category [3]. Also, a group of scientists led by A.V. Vakhobov proposed to approach the analysis of the financial condition of economic entities through a comprehensive system of indicators, using complex methods [4]. These scholars organized the rational management of enterprises, firms and companies in economically independent and financially stable activities, the basis of accounting in accordance with the requirements of a market economy, financial 
management, production or service with efficient use of available material, financial and labor resources. The importance of financial analysis in addressing issues such as achieving high returns as a result is highlighted [5].

Although leasing services have been relatively little studied scientifically, the issue of creditworthiness of the borrower, especially the lessee, has been widely discussed in the foreign scientific literature. In particular, the creditworthiness of the bank borrower was studied by Russian economists Bondarenko C.B. [6], Ilyasov S.M. [7], Kovalev V.A., Voronova E.A. [8], Sokolova H.A. [9], Bespalova V.I. [10] The issues of financial analysis that can be used to evaluate the lessee are covered by Balabanov I.T. [11], Blank I.A. [12], Bocharov V.V. [13], Efimova O.V. [14], Kovalev V.V., Sokolova N.A. [15], Sheremeta A.D. [16].

\section{Main Part}

Due to the fact that the credit risk associated with the lessee's late payment is significant for the leasing company, the lessee's financial condition plays a key role in evaluating the project. It is therefore advisable to perform a financial analysis of the lessee's activities using specific financial indicators. The following indicators are used in our national economy:

$>$ solvency or coverage ratio - SCR;

$>$ own working capital ratio - OWCR;

$>$ return on assets and expenses - RAE.

The following additional indicators can also be used to make a final decision:

$>$ ratio of own and short-term borrowings - ROSB;

$>$ production capacity utilization factor - PCUF;

$>$ depreciation rate of fixed assets - DRFA.

In this case, the enterprise to be financially analyzed, ie the lessees are selected by the following indicators:

$>$ the presence of accounts payable on paid obligations and mandatory payments overdue for more than three months from the date of their payment;

$>$ insolvency of the enterprise, i.e. inability to cover short-term debts with current assets;

$>$ low profitability or loss.

The values of these indicators are given in the following table (Table1). 
Table 1: Financial indicators used in determining the financial condition of economic entities in our national economy and their importance $[1,17]$

\begin{tabular}{|l|l|l|l|}
\hline \multirow{2}{*}{ № } & \multicolumn{1}{|c|}{ Indicators } & \multicolumn{1}{|c|}{$\begin{array}{c}\text { The essence of the } \\
\text { final indicator }\end{array}$} & \multicolumn{1}{c|}{ Financial condition } \\
\hline 1 & Solvency ratio & $>1.25$ & The enterprise has the ability to pay \\
\hline 2 & Own working capital ratio & $\begin{array}{l}\text { Own working capital } \\
\text { ratio } \geq 0.2\end{array}$ & $\begin{array}{l}\text { Equipped with its own working } \\
\text { capital }\end{array}$ \\
\cline { 3 - 4 } 3 & Profitability coefficient & $0<\mathrm{R}_{\mathrm{k}}<0.05$ & Working at a loss \\
\hline 4 & $\begin{array}{l}\text { The ratio of own and short- } \\
\text { term debt }\end{array}$ & $>1$ & Low profitability of the enterprise \\
\hline 5 & $\begin{array}{l}\text { Coefficient of utilization of } \\
\text { production capacity }\end{array}$ & $>0.5$ & $\begin{array}{l}\text { The utilization rate of the enterprise's } \\
\text { production capacity is high }\end{array}$ \\
\hline 6 & $\begin{array}{l}\text { Depreciation rate of fixed } \\
\text { assets }\end{array}$ & $>0.5$ & $\begin{array}{l}\text { The main tools are significantly } \\
\text { outdated }\end{array}$ \\
\hline
\end{tabular}

By determining these indicators, business entities are divided into the following groups according to their economic status:

$>$ economically viable;

$>$ economic risk;

$>$ economically insolvent:

$>$ able to restore solvency;

$>$ unable to restore solvency.

The "economically viable" group includes business entities that are not included in the "economic risk" and "economically insolvent" groups.

Business entities belonging to the group "Economic risk" are identified based on the presence of signs of insolvency listed in line 1 of Table 1 or signs of low profitability and financial risk listed in lines 3-4 .

Business entities belonging to the group of "economically insolvent" are determined on the basis of the presence of accounts payable for overdue payments and mandatory payments overdue for more than three months from the date of their payment. In this case, the business entities that are "able to restore solvency" are those that are able to repay the debt under the above condition. Business entities with overdue accounts payable in the amount specified in the legislation belong to the subgroup "insolvency" if there are signs of insolvency, low profitability (loss) and lack of working capital.

The recipient of limited leasing is widely used methods to assess the result of the comparison, to consider internationally as a method of evaluation that meets the requirements of the most limited assessment of the model as a whole. This method involves determining a credit rating based on adjustments that can be made by an expert. Credit rating is determined by a formula that includes a certain quantity and quality indicators. As a rule, only quantitative indicators are used, while qualitative indicators are applied only when they are quoted and standardized. However, due to the fact that the classical rating model of assessing the creditworthiness of the borrower does not take into account the specifics of leasing activities and the risk of the leasing company, we try to change the classical rating model of leasing project evaluation to a multi-factorial complex model of assessment (see Figure 1). 


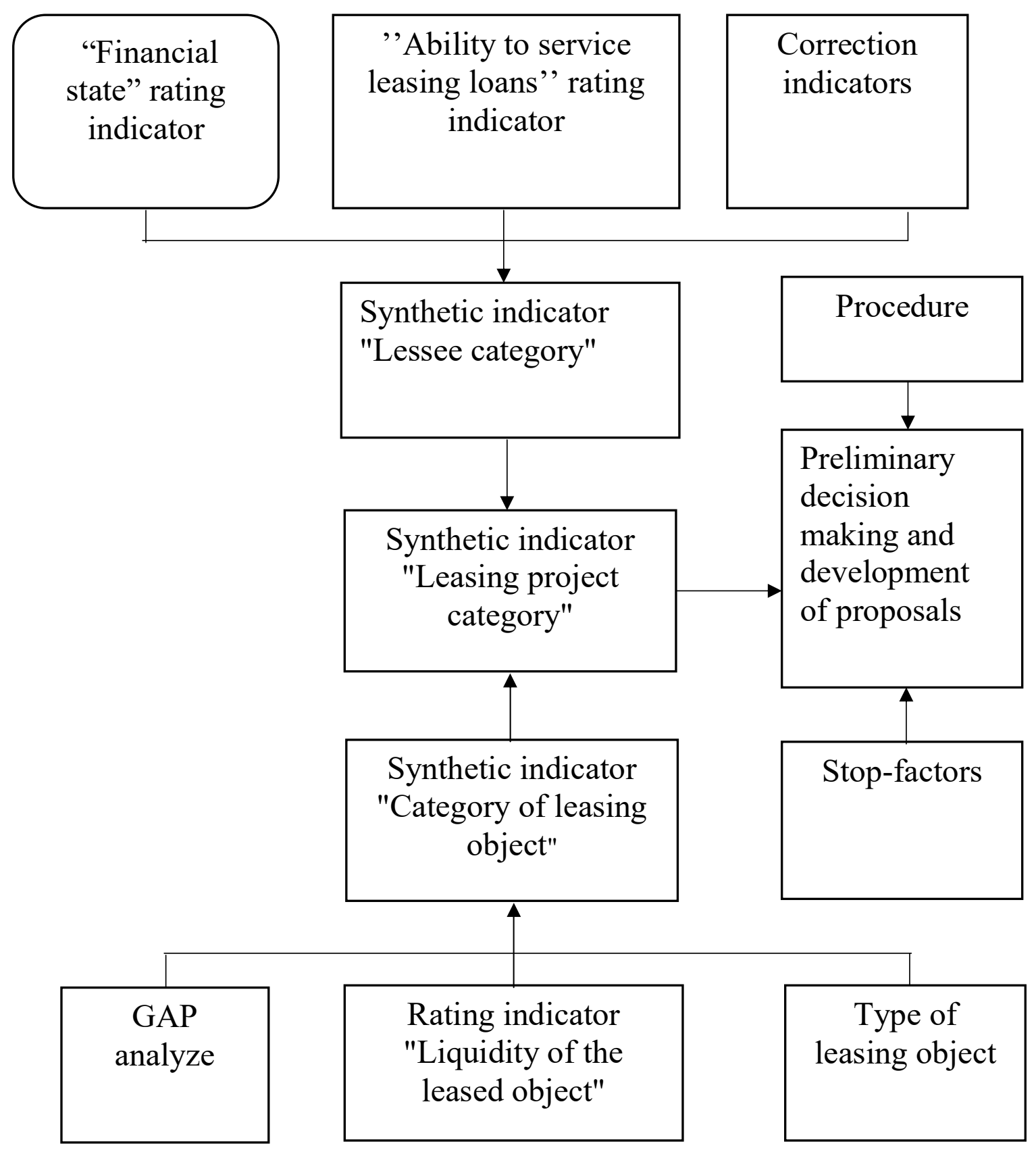

Figure 1. Multi-factorial complex methodology of leasing project evaluation [18]

The main elements of this methodology are the "Lease Category", "Leasing Object Category", "Leasing Project Category", a list of constraints or stop-factors, and a model process governing the development and decision-making process based on the indicators obtained.

The development of a limited expert rating rating model includes steps based on expert opinion and statistical analysis. In the first stage, the indicators used in determining the rating are determined. In the second stage, each indicator or its share, the share of which is reflected in the specific gravity and affects the final rating, is determined. In the third stage, each indicator is evaluated and the final rating indicator is determined. We represent these steps in the form of the following diagram (Figure 2). 


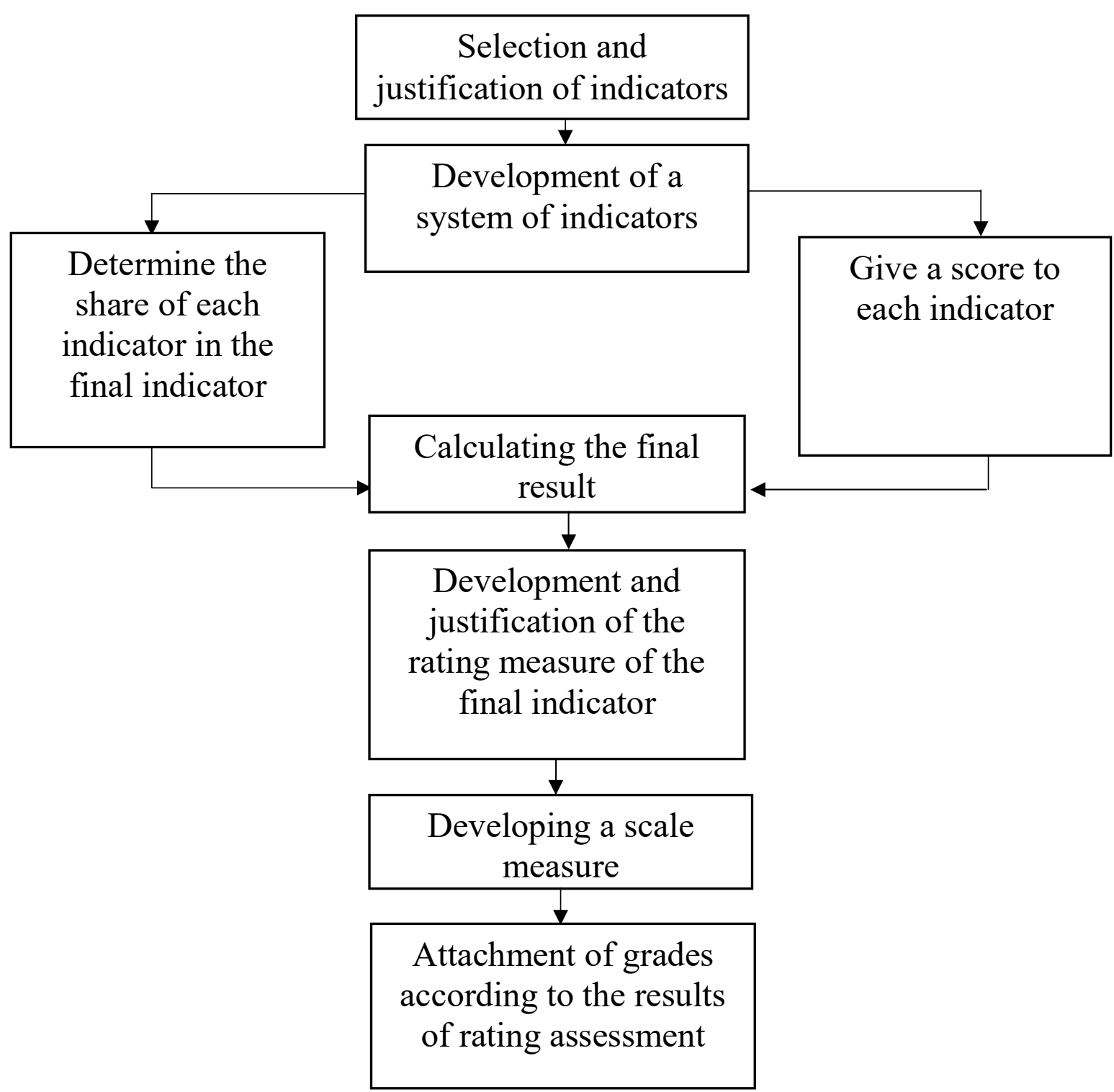

Figure 2. Scheme of stages of development of rating system [18]

There are a number of problems with the use of rating models. One of the main problems is the interconnection of various indicators and the elimination of contradictions. However, there are no strictly defined or recommended indicators that are mandatory in determining the final rating. In international practice, a number of financial indicators (coefficients) are used to determine the financial condition of business entities. But there is no single list of them either. We list the most common and commonly used indicators below:

$>$ Liquidity;

$>$ Solvency;

$>$ Financial stability, independence;

$>$ Capital structure;

$>$ Financial leverage;

$>$ Business (asset turnover);

> Profitability. 
The amount of financial ratios recommended in the analysis of the financial situation can be very large. Nevertheless, carefully selected financial indicators are one of the key stages in the development of a rating assessment methodology, as they should fully reflect the financial condition of business entities, and making a mistake in the selection of indicators leads to a violation of the rating. The purpose of the analysis of the financial condition of business entities is to determine the amount and set of indicators required to obtain complete information (imagination) about their financial condition. At the same time, we can cite indicators that must be analyzed as the most important indicators.

In international practice, the coefficients listed in Table 2 are selected for the purpose of financial evaluation of the lessee.

Table 2: Coefficients used in financial evaluation in international practice [18]

\begin{tabular}{|c|c|c|}
\hline № & Naming of the ratio & Calculation formula \\
\hline 1 & Total liquidity ratio K1 & $\begin{array}{l}\mathrm{K}_{1}=\frac{\left(A_{1}+\frac{1}{2} A_{2}+\frac{1}{3} A_{2}\right)}{\left(P_{1}+\frac{1}{2} P_{2}+\frac{1}{3} P_{9}\right)} \\
\mathrm{A}_{1}, \mathrm{~A}_{2}, \mathrm{~A}_{3}-\text { types of assets of the enterprise for sale, } \\
\mathrm{P} 1, \mathrm{P} 2, \mathrm{P} 3 \text { - business liabilities for the payback period }\end{array}$ \\
\hline \multirow{2}{*}{2} & \multirow[t]{2}{*}{ Coverage ratio $\mathrm{K} 2$} & Working capital (balance 390 linas) \\
\hline & & Short-tarm liabilitias (balance shat 600 linas) \\
\hline \multirow{2}{*}{3} & Self-sufficiency ratio & \multirow{2}{*}{$\mathrm{K}_{3}=\frac{\text { Currant assats (balanca shatt } 480 \text { linas) }}{\text { Sourcas of aguity (balance total } 400 \text { knes) }}$} \\
\hline & & \\
\hline \multirow[t]{2}{*}{4} & \multirow[t]{2}{*}{$\begin{array}{l}\text { Autonomy ratio (financial } \\
\text { independence) }\end{array}$} & $\mathrm{K}_{4} \quad$ Private capital (balance 480 lines) \\
\hline & & Total proparty of tha antarprisa (balance total 400 linas) \\
\hline \multirow{2}{*}{5} & \multirow{2}{*}{ Sales profitability ratio } & \multirow{2}{*}{$\mathrm{K}_{5}=\frac{\text { Profit from operating activities }}{\text { Net income from sales (Figure } 2 \text {, line } 010)}$} \\
\hline & & \\
\hline \multirow{2}{*}{6} & \multirow{2}{*}{$\begin{array}{l}\text { Coefficient of total } \\
\text { profitability of activities }\end{array}$} & \multirow{2}{*}{$\mathrm{K}_{6}=\frac{\text { (Net profit (Figure 2,line 270) }}{\text { (Net profit from sales (Figure 2,line } 010}$} \\
\hline & & \\
\hline 7 & Growth of revenue & $\begin{array}{l}\mathrm{K}_{7}=((\text { Amount of revenue in the current period }) / \text { (Amount of } \\
\text { revenue in the previous period })) * 1 / \mathrm{n}-1\end{array}$ \\
\hline
\end{tabular}

When selecting a potential lessee, the lessor is required to analyze not only the indicators listed in the table above, but also in addition to such indicators as financial stability, performance, profitability, financial leverage [19] .

There are no single recommendations or restrictions on which of the above indicators are normative or critical in illuminating the nature of financial indicators. According to AM Tavasiev, in covering the essence of indicators in the United States and Europe, it is recommended to compare these indicators with previous indicators of business entities and the average performance of the industry to which the entity belongs [20]. However, it is not possible to apply this recommendation in the economies of all countries. The main reasons for this are the constant changes in the legal framework (tax legislation, the development of accounting and reporting rules, other regulations), the impact of inflation, as well as the lack of initial indicators. It is also very difficult to compare the performance of the analyzed enterprise with the performance of the network due to the lack of normative network indicators. Due to this, the threshold values of the indicators are developed on the basis of the legislation of the country. The following intervals are used to determine the scores for the above 
seven $\mathrm{m}$ high indicators (Table 4).

Table 4: Score of financial indicators in the rating of the financial situation [18]

\begin{tabular}{|l|l|l|l|l|}
\hline Indicator & 1 point & 2 points & 3 points & 4 points \\
\hline $\mathrm{K}_{1}$ & $\geq 1$ & {$[0.75 ; 1)$} & {$[0.5 ; 0.75)$} & $<0.5$ \\
\hline $\mathrm{K}_{2}$ & $\geq 1.5$ & {$[1,3 ; 1.5)$} & {$[1 ; 1,3)$} & $<1$ \\
\hline $\mathrm{K}_{3}$ & $\geq 0.1$ & {$[0 ; 0.1)$} & {$[-0.1 ; 0)$} & $<-0.1$ \\
\hline $\mathrm{K}_{4}$ & $\geq 0.5$ & {$[0.3 ; 0.5)$} & {$[0.1 ; 0.3)$} & $<0.1$ \\
\hline $\mathrm{K}_{5}$ & $\geq 0.1$ & {$[0.05 ; 0.1)$} & {$[0 ; 0.05)$} & $<0$ \\
\hline $\mathrm{K}_{6}$ & $\geq 0.05$ & {$[0.03 ; 0.05)$} & {$[0 ; 0.03)$} & $<0$ \\
\hline $\mathrm{K}_{7}$ & $\geq 0.1$ & {$[0.05 ; 0.1)$} & {$[0 ; 0.05)$} & $<0$ \\
\hline
\end{tabular}

The share of each indicator in the final rating varies depending on the leasing company's credit policy, the goals and objectives of the analysis. In determining the proportion of indicators, it follows that their sum must be equal together. When the number of indicators is large, it is advisable to use the Fishburn scheme to determine their share. The procedure for constructing the Fishburn scheme is as follows [21]:

1. Initially, $\mathrm{p}_{\mathrm{i}}$ images are determined based on the following scheme:/

$\mathrm{p}_{\mathrm{i}}=\max \left(\mathrm{pr}_{1}, \ldots, \mathrm{pri}, \ldots, \mathrm{pr}_{\mathrm{n}}\right)-\mathrm{pr}_{\mathrm{i}}+1$,

Here:

$\max \left(\mathrm{pr}_{1}, \ldots, \mathrm{pr}_{\mathrm{i}}, \ldots, \mathrm{pr}_{\mathrm{n}}\right)$ - the maximum amount of the value (priority) of the indicators;

pri $-\mathrm{s}$ the value (priority) of the indicator.

2. The denominator of the Fishburn fraction is determined. The sum of the images is the denominator of the Fishburn fraction:

$$
\mathrm{K}=\sum_{\bar{i}=1}^{n} p_{i}
$$

3. Knowing the image and denominator of the Fishburn fraction, it is possible to determine the proportion of the figure:

$$
\mathrm{r}_{\mathrm{i}}=\frac{p_{i}}{K}
$$

Hence, for each financial indicator, their shares are determined based on the Fishburn scheme and the results are presented in tabular form (Table 5).

Initially, pi images are determined based on the following scheme:

$\mathrm{p}_{\mathrm{i}}=\max \left(\mathrm{pr}_{1}, \ldots, \mathrm{pri}, \ldots, \mathrm{pr}_{\mathrm{n}}\right)-\mathrm{pr}_{\mathrm{i}}+1$,

Here:

$\max \left(\mathrm{pr}_{1}, \ldots, \mathrm{pr}_{\mathrm{i}}, \ldots, \mathrm{pr}_{\mathrm{n}}\right)$ - the maximum amount of the value (priority) of the indicators;

$\mathrm{pr}-$ is the value (priority) of the indicator.

The denominator of the Fishburn fraction is determined. The sum of the images is the denominator of the Fishburn fraction:

$$
\mathrm{K}=\sum_{i=1}^{n} p_{i}
$$


Knowing the image and denominator of the Fishburn fraction, it is possible to determine the proportion of the figure:

$$
\mathrm{r}_{\mathrm{i}}=\frac{p_{i}}{K}
$$

It means that for each financial indicator, their shares are determined based on the Fishburn scheme and the results are presented in tabular form.

Table 5:The share of indicators in the rating of "financial condition" [18]

\begin{tabular}{|l|l|}
\hline Financial performance & Percentage of indicator \\
\hline $\mathrm{K}_{1}$ & 0.17 \\
\hline $\mathrm{K}_{2}$ & 0.33 \\
\hline $\mathrm{K}_{3}$ & 0.11 \\
\hline $\mathrm{K}_{4}$ & 0.06 \\
\hline $\mathrm{K}_{5}$ & 0.13 \\
\hline $\mathrm{K}_{6}$ & 0.07 \\
\hline $\mathrm{K}_{7}$ & 0.13 \\
\hline
\end{tabular}

We use the following formula to determine the final figure:

$$
\mathrm{K}_{\text {final }}=\sum_{1}^{n} K_{n} * \omega_{n}[18],
$$

Here:

$K_{n}$ - score of the nth indicator;

$\omega_{n}$ - The share of the nth indicator.

Credit institutions, in particular leasing companies, are required to classify borrowers (lessees) on certain scales after determining the rating. According to the Basel Committee, an average of 8 to 11 different scales are used to assess creditworthiness [22]. The number of these scales is determined independently by the credit institution (leasing company) based on its needs and for the purpose of giving a credit rating. A small number of scales are used by small lending institutions (or leasing companies) to forecast the quality of their loan portfolio. The number of rating scales is increased by commercial banks (leasing companies), which determine the level of profitability and credit risk on the basis of credit ratings. Nevertheless, an excessive increase in the number of scales leads to a practical equalization of the difference between the indicators.

Therefore, the number of scales should be set at a rate equal to the number of points to evaluate financial performance. The range and limits of rating indicators should be determined based on the goals and objectives of the methodology for determining them. 1 point is taken as the evaluation criterion, i.e. the higher the score, the lower the financial status. If all indicators show the highest result, then the final rating indicator will be 1 . As a rule, the highest value corresponds to its highest absolute value, but it is advisable to start from a basis that is clear for comparison (Table 6 ).

Table 6: Scales for rating the financial condition [18]

\begin{tabular}{|l|l|l|}
\hline Scale & The essence of the final indicator & Financial condition \\
\hline 1 & {$[1 ; 1,3]$} & A'lo \\
\hline 2 & $(1,3 ; 2]$ & Good \\
\hline 3 & $(2 ; 2,6]$ & Satisfactory \\
\hline 4 & $>2.6$ & Unsatisfactory \\
\hline
\end{tabular}




\section{Conclusion}

In conclusion, in the practice of Uzbekistan, the practice of comprehensive study of the financial condition of business entities, especially lessees, is rarely used. We rarely encounter real analytical data based on the data of the leasing business entities in any source. Often, these analyzes are determined on the basis of approximate, conditional sources obtained from businesses that do not use the leasing service. This is also the case with the dynamic changes in financial performance over the years.

In addition, our legislation also differs from foreign practice in determining financial performance. In particular, there are differences in the different naming, composition, and order of identification of indicators. Therefore, when choosing a lessee, we offer the following suggestions:

1. In the published sources, in the calculation of indicators, it is necessary to clearly indicate from which form and lines of financial statements the data are taken. In this way it is possible to ensure their accuracy and uniformity;

2. to lease the leasing market, the assessment of its financial position through the development of guidance for decision-making. This guideline should clearly define the necessary indicators that allow to determine the financial condition of the lessee, based on factors such as the specifics of the activities of the lessee, the field of activity, the term of the lease ;

3. In order to make a comprehensive financial analysis of the activities of lessees, it is necessary to use the rating assessment based on the Fishburn scheme, to draw conclusions from the share of indicators in the final result.

\section{References}

1. Burkhanov A.U. Method of assessing the financial stability of industrial enterprises // Scientific electronic journal "Economy and Innovative Technologies". № 6, November-December, 2018.

2. Khakimov B., Kholmirzaev U. Improving cash accounting and analysis based on international experience. Scientific electronic journal "International Finance and Accounting". № February 1, 2020, www.interfinance.uz/en/

3. Rakhimov M. Analysis of the financial condition of economic entities. Study guide. T.: "Economics and Finance", 2015. 34-p.

4. Vakhabov AV, Ishankulov NF, Ibragimov AT "Financial and management analysis". Textbook. T.: "Economy-Finance", 2013. 299-p.

5. Vakhabov A.V., Ibragimov A.T. Financial analysis. Textbook. - T.: "Uzbekistan", 2002., 230 p. http://arm.sies.uz/wp-content/uploads/2020/10/13-y-Financial-analysis-Darslik-A-VoxobovT2002.pdf

6. Bondarenko S.V., Saprunova E.A. Comparative analysis of the methodical assessment of the creditworthiness of the borrower. - «Finance and credit», 2008., №24 (312) - p.12-17.

7. Ilyasov S.M. On the assessment of the creditworthiness of a bank borrower. - "Money and Credit", 2005, No. 9. - p. 28-32.

8. Kovalev Vit. V., Voronova E.A. (2019) Logic and criteria for assessing the financial condition of a leasing company. Bulletin of St. Petersburg University. Economy. T. 35. Issue. 1.S. 50-82. https://doi.org/10.21638/spbu05.2019.103/

9. Sokolova H.A. Assessment of the borrower's creditworthiness: what the bank is interested in. "Accounting", No. 11 June 2008. - p. 58-63. 
10. Bespalova V. I. Fundamentals of the coefficient method for analyzing the financial stability of an organization / V. I. Bespalova. // Young scientist. - 2019. - No. 45. - P. 275-278. - URL: https://moluch.ru/archive/283/63702/ (date of access: 10.12.2019).

11. Balabanov I.T. Analysis and planning of the finances of an economic entity. - M.: Finance and statistics, 1998. - 109s.

12. Bank V.R., Bank S.V., Taraskina JI. V. Financial analysis: textbook. allowance. - M.: TK Welby, Prospect Publishing House, 2006. - 344 p.

13. Bocharov V.V. Comprehensive financial analysis. - From Pb: Peter, 2005. - 432s.: Ill. - (Series "Academy of Finance").

14. Efimova O.V. The financial analysis. 4th ed., Rev. and add. - M.: Accounting, 2002. - 528s.

15. Sokolova H.A. Assessment of the borrower's creditworthiness: what the bank is interested in. "Accounting", No. 11 June 2008. - p. 58-63.

16. Sheremet A.D. Comprehensive analysis of economic activities. - M.: INFRA-M, 2006. - 415p.

17. Resolution of the Cabinet of Ministers of the Republic of Uzbekistan dated December 14, 2018 No 1013 "On measures to radically improve the system of financial rehabilitation of enterprises with state participation"

18. Bagretsova N.V. Multifactorial financial assessment of a leasing project based on the analysis of the financial condition: author ... dis. can. econom. sciences. - M.: 2013. - 36 p.

19. V.A. Goremykin. "Planning and economic department" // Financial management. No. 112012. https://www.profiz.ru/peo/11_2012/lizingopolychatel/

20. Banking. Management and technology: textbook. for university students enrolled in economic specialties / Ed. prof. A. M. Tavasieva. - Moscow: 2nd ed. Revised And add. M.: UNITI-DANA, 2005.- $671 \mathrm{p}$.

21. Gorelaya N.V. Assessment of the borrower's creditworthiness in the credit risk management system. // Corporate finance management. No. 5., 2005, p. 13 [Electronic resource]: Access mode: http://grebennikon.ru/search_page.ph./

22. Bogatyreva M.M. Assessment of the borrower's creditworthiness in the context of the new requirements of the Basel Committee // Economic Bulletin of Rostov State University. No. 4, volume 5., 2007 https://cyberleninka.ru/article/n/otsenka-kreditosposobnosti-zaemschika-vkontekste-novyh-trebovaniy-bazelskogo-komiteta/ 